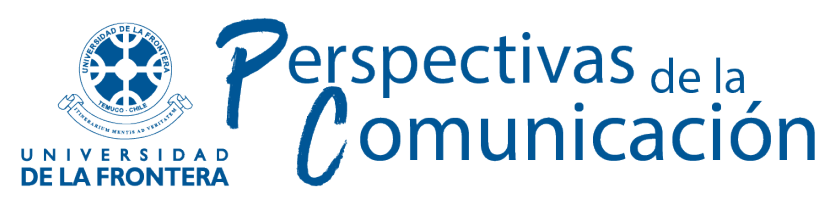

ISSN 0718-4867

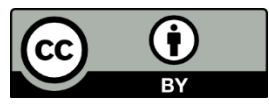

Artículo

\title{
CONSTRUCCIÓN DE MEMORIA EN LA NUEVA HISTORIETA HISTÓRICA RIOPLATENSE: LOS CASOS MALANDRAS Y TACUARA DE RODOLFO SANTULLO Y DANTE GINEVRA
}

DOI: POR DEFINIR

Dr. Sebastian Horacio Gago

Facultad de Ciencias de la Comunicación, Universidad Nacional de Córdoba; IECET (Conicet y FCC-UNC), Córdoba, Argentina.

sebastian.gago@unc.edu.ar

ORCID iD: https://orcid.org/oooo-0001-8887-4842

Recibido el 2020-09-15

Revisado el 2021-11-26

Aceptado el 2021-12-09

Publicado el 2021-12-15

\section{Resumen}

Analizamos dos historietas guionadas por Rodolfo Santullo y dibujadas por Dante Ginevra: Malandras (2010-2011) y Tacuara (2012). Publicadas en la revista argentina Fierro, estas ficciones se estructuran en base a operaciones significantes de reconstrucción y recuperación del pasado. Aunque ubicadas en lugares diferentes dentro del sistema de géneros de aventuras tradicional (una más policial y la otra, política), ambos cómics están atravesadas por lo político. Y son historietas históricas porque producen sentido a partir de acontecimientos y actores cuyas propiedades y características centrales ya han sido configuradas en discursos marcados por su función referencial y en tiempo pasado, en especial por la historiografía y por el periodismo (Berone, 2018, p. 41). La nueva historieta histórica rioplatense explota la condición de la historieta como medio expresivo para construir memoria colectiva y revisar el pasado, dando sentido a acontecimientos históricos bajo cierto contexto producción -en especial el imaginario social sobre el pasado construido en un particular presente.

Palabras clave: Historia, narrativa, ficción, memoria, historieta. 


\title{
MEMORY CONSTRUCTION IN THE NEW RIVER PLATE HISTORICAL COMIC: THE CASE OF MALANDRAS AND TACUARA (SANTULLO-GINEVRA)
}

\begin{abstract}
In this paper, we analyze two comic strips: Malandras (2010-2011) and Tacuara (2012), both scripted by Rodolfo Santullo and drawn by Dante Ginevra. Published in the Argentine magazine Fierro, these fictions can be recognized as attempts to reconstruct and analyze the past. Although they can be classified as different subgenres within the broad traditional adventure genre (one can be classified as part of the police genre and the other, as an example of the political genre), both comics are centered around political aspects. We maintain that they are historical comics because they produce meaning from events and actors whose central properties and characteristics have already been configured in discourses marked by their referential function, especially by historiography and journalism (Berone, 2018, p. 41). The new historical story comics from the River Plate exploit the condition of graphic narratives as an expressive means to build collective memory and review the past, giving meaning to historical events under a certain context - especially the social imaginary about the past built in a singular present.
\end{abstract}

Keywords: History, narrative, fiction, memory, comic. 


\section{Introducción}

En este texto nos proponemos analizar un objeto inscripto en el arte y en las industrias culturales, como lo es la historieta en su función de recuperadora de memoria en el ámbito del Río de la Plata. Consideramos en esta primera parte del texto incluir una breve historización del objeto.

Durante la segunda etapa de su dilatada y discontinua vida editorial (2006-2017), la revista Fierro, publicada en ese entonces por el diario Página/12, propuso y dio lugar a producciones historietísticas que plantearon la reconstrucción de una memoria histórica de la Argentina. Ese criterio se desprendió de una línea editorial similar a la tradición de la primera Fierro, publicada por Ediciones de la Urraca entre 1984 y 1992. Aquel proyecto nacido en plena recuperación democrática del país, presentaba como tema dominante a la idea de hacer visible lo oculto, lo negado u oprimido, y así develar la memoria "verdadera" a través de representaciones del terrorismo de Estado dictatorial, como puede apreciarse en las series Ficcionario (Horacio Altuna), La batalla de las Malvinas (guión de Ricardo Barreiro y dibujos de Carlos Pedrazzini y Marcelo Pérez), La Triple B (Félix Saborido y Carlos Albiac), Sudor Sudaca (Carlos Sampayo y José Muñoz), y Perramus (Juan Sasturain y Alberto Breccia).

La segunda época de la revista, iniciada en noviembre de $2006^{1}$, se caracterizó por otro tipo de formas y estilos a la hora de encarar el problema de la representación no ya solamente de los horrores de la última dictadura argentina, sino también de episodios traumáticos de la historia nacional anterior y posterior a aquel régimen genocida. Al concepto de representación lo ceñimos puntualmente al análisis de una serie de usos específicos para este medio expresivo en el ámbito rioplatense. En ese sentido, la incorporación del tratamiento de la política en la historieta narrativa fue una novedad a partir de la ampliación del espacio de lo decible y lo visible en los años 8o. La constitución de un espacio editorial como Fierro (en su primera época) fue a contrapelo de la tendencia tradicional de la

\footnotetext{
${ }^{1}$ La segunda época de la revista Fierro se desarrolló bajo la dirección de Juan Sasturain y la jefatura de redacción de Lautaro Ortiz. Esta experiencia editorial duró hasta marzo de 2017, cuando Fierro abandonó su periodicidad mensual. En su tercera época, la revista, de frecuencia trimestral, fue dirigida por Lautaro Ortiz, con final en abril de 2019. En septiembre de 2020, Fierro inició su cuarta época, publicada no ya por Editorial La Página (la misma que edita el diario Página/12) sino por el diario digital El Destape, con Lautaro Ortiz en la dirección.
} 
historieta a la despolitización, es decir, a ser un medio que "no suele admitir de manera explícita las tensiones sociales contemporáneas a su creación” (Berone, 2012, p. 43). La actualización y renovación del tratamiento de un problema que forma parte del campo cultural de la transición democrática argentina (Reggiani, 2008), se extiende hasta el presente. Fierro, ya en su segunda etapa editorial, propuso a través de criterios y recursos variados la reconstrucción de una memoria fragmentaria, basada en relatos, testimonios y documentos históricos, desde la ficción o combinando estos regímenes discursivos. Como ejemplos paradigmáticos citamos sólo algunas series representativas de esta nueva forma genérica publicadas en la revista argentina: Edén Hotel (Diego Agrimbau y Gabriel Ippolitti, 2012), Dora (Ignacio Minaverri, 2009 y 2012), y los dos títulos bajo estudio guionados por Rodolfo Santullo y dibujados por Dante Ginevra, Malandras y Tacuara. Sin pretensión de exhaustividad, mencionamos otros exponentes del género, no publicados en Fierro: Acto de Guerra (guion de Santullo y dibujo de Matías Bergara, 2010), Zitarrosa (Santullo y Max Aguirre, 2012), Tupamaros: La Fuga/1971 (Roy Leguisamo y Lauri Fernández, 2013), Morir por el che: 1961 (Roy Leguisamo, dibujos de Marcos Vergara y color de Caio Di Lorenzo, 2012), Camino a Auschwitz y otras historias de resistencia (Julián Gorodischer y Marcos Vergara, 2015) e Historietas por la identidad (Varios artistas, 2011).

El histórico es tal vez el género más importante del cómic contemporáneo rioplatense. Decimos rioplatense porque, del conjunto de las obras que lo conforman, una buena parte se desarrolló en zonas de intersección entre ambos países, Argentina y Uruguay, ya sea en las esferas de producción y edición como de circulación y recepción dentro del campo de la historieta. Ponemos como ejemplo obras realizadas por duplas creativas de ambos países, como el caso de las dos bajo estudio, Malandras y Tacuara, a las que agregamos las mencionadas Zitarrosa (Santullo es uruguayo y Aguirre es argentino), Tupamaros: La Fuga/1971 (Roy es uruguayo y Fernández es argentina) y Morir por el che: 1961 (Roy y los argentinos Vergara y Di Lorenzo). En el caso de las dos últimas, ambas ganadoras de los Fondos Concursables para la Cultura del Ministerio de Educación y Cultura del Uruguay fueron coeditadas por los sellos Loco Rabia (Argentina) y Dragón Comics (Uruguay).

Para rastrear los orígenes del género, nos remitimos a la década del 6o del siglo XX, en un estado del campo de la historieta de aventuras argentina cuyo sistema de géneros narrativos se estructuraba, según Berone (2014), en tres grandes categorías: 1) los géneros de la Modernidad, entre los que sitúa el melodrama, el policial y el relato de ciencia ficción (subdividiendo esta subcategoría entre la ciencia ficción y lo maravilloso); 2) los géneros 
fundadores de una épica moderna occidental, clasificados en western (la versión local argentina sería la gauchesca) y la historieta de guerra; 3) finalmente, los géneros cuyas aventuras se plantean desde una lejanía espacial y temporal ${ }^{2}$. Este segundo tipo de lejanía, que corresponde a la denominada historieta histórica, presenta mundos ficcionales situados en un período determinado del pasado (Antigüedad, medioevo, etc.).

Las historietas de tema histórico irrumpen con fuerza en los años 60, momento en que "la historia se convierte en temática” en los cómics (Lladó-Pol, 2001, p. 76). Sin renunciar a la ficción ni a su pretensión de verosimilitud, los cómics de época producen interpretaciones de las circunstancias sociales y políticas del pasado y, en algunos casos, las narraciones son acompañadas por logrados elementos fantásticos. Sin embargo, el mecanismo narrativo de situar los hechos en periodos históricos lejanos es propio también de algunos géneros de aventura clásicos que podríamos ubicar dentro de la segunda categoría planteada por Berone (por ejemplo, western, gauchesca, bélico) y en algunas series de ciencia ficción. Y también observamos el mismo mecanismo en los cómics biográficos o en la "historieta histórica" tradicional, cuya pretensión es la de ser un discurso portador de verdad o el admitir solamente una lectura moral, o alegórica, de los hechos históricos que representa (Berone, 2020, p.21). Dentro de este género, se destaca Latinoamérica: 450 años de Guerra, una serie de relatos revisionistas de la Historia latinoamericana que Héctor Oesterheld escribiera durante su trayectoria tardía, al calor de su militancia política revolucionaria.

La diferencia entre el género "histórico" tradicional y la historieta histórica contemporánea radica en la naturaleza política de ésta última, que no deja afuera la dimensión actual de los hechos históricos que representa en la ficción (Berone, 2020). La lectura actual de los hechos del pasado es construida a partir de la forma discursiva del testimonio, que implica un modo particular de concebir la relación entre subjetividad e Historia (Berone, 2020): la Historia puede conocerse no ya a partir de una versión objetiva de los hechos, sino de la

\footnotetext{
${ }^{2}$ La teorización sobre los géneros de la historieta forma parte de la clase titulada "El sistema de los géneros en la historieta argentina contemporánea. El caso de la historieta histórica", que Lucas Berone impartió en el curso "¿Y qué pasó con la autonomía? Debates en torno a las nuevas prácticas en el campo de la historieta" a cargo del proyecto de investigación "Estudios y Crítica de la Historieta II" (Secyt, FCC-UNC). El curso fue dictado dentro del marco del proyecto de Extensión desde las Cátedras “Autonomía y nuevas posiciones en el campo de la historieta argentina”, en la Escuela de Ciencias de la Información, Universidad Nacional de Córdoba, septiembre de 2014. Texto inédito.
} 
experiencia (p.31). De manera que las narraciones inscritas en el género nueva historieta histórica rioplatense (NHHR) (ibíd.) parten de hechos y personajes históricos como base. Dentro de los límites de este nuevo género, las narraciones presentan un carácter testimonial a partir de la combinación, en mayor o en menor medida, de elementos documentales y monumentales, y la inclusión de estrategias de evocación y cruces entre la monumentalidad (la significación cultural) de las figuras históricas (Berone, 2020, p.23) convertidas en personajes. Estas historietas contemporáneas aprovechan las conocidas dificultades que se experimentaron, y se experimentan, a la hora de documentar fehacientemente una serie de hechos históricos narrativizables y que resultan caros a este género (por dar ejemplos de estos hechos, podríamos mencionar muertes o circunstancias de la muerte de una figura histórica, encuentros y conversaciones que involucran a estas figuras, los pormenores y la autoría de un crimen político, entre otros).

Ahora bien, el tratamiento de la temática política y la apelación a la memoria histórica, dos aspectos que definen a la NHHR, trascienden la experiencia de Fierro. Señalan Savoini y Siragusa (2017, p. 17) que "rememorar" es una práctica social compleja plena de significación, e implica instalar en el presente un acontecimiento del pasado a partir de un esfuerzo de memoria. La apelación a la memoria en torno a distintas etapas y episodios traumáticos de la historia de los países del Río de la Plata, la reciente y la no tan reciente -y, dentro de esta línea, el tratamiento de hechos políticos relacionados con el peronismo en el caso argentino-, emergió en un contexto socio-histórico ligado a una serie de políticas de fomento a la producción de contenidos massmediáticos -audiovisuales, literarios, historietísticos- desde el Estado, que en la Argentina tuvo lugar a partir de mediados de la década del 2000 hasta la mitad del decenio siguiente. "Puede conjeturarse que la expansión de estas operaciones recordatorias es posible por una cierta preeminencia de una 'apertura a la subjetividad' como rasgo epocal" (Savoini \& Siragusa, 2014, p.17). Ese rasgo de época se expresó en políticas de memoria, justicia y reparación simbólica impulsada por los gobiernos de Néstor y de Cristina Kirchner en Argentina (2003-2015), y un proceso similar llevado adelante por el Estado-Gobierno uruguayo a partir del triunfo electoral del Frente Amplio en 2005 (Martínez-Guidolin, 2015). Asimismo, la producción de contenidos ficcionales basada en la memoria histórica, al menos en el campo de la historieta, se puede leer como una respuesta estratégica de este medio cultural hacia las aludidas políticas y gestos específicos de intervención de los respectivos Estados rioplatenses en el seno del mismo. En otras palabras, desde el cómic emergieron una serie de discursos que "se ocupan de (re)construir un pasado reciente traumático a partir de relatos artísticos, vinculados 
directamente con las políticas de D.D.H.H” (Fernández, 2017, p. 193). Sin pretensión de exhaustividad, pero sí a modo orientativo, resumimos esas políticas en los siguientes puntos:

1) En el caso argentino, desde 2003 el Estado implementó unas medidas de incentivo al medio historietístico, muchas de las cuales fueron discontinuadas a partir del cambio de signo político del Gobierno nacional en 2015. Entre estas políticas o gestos, alistamos las siguientes: a) el apoyo con pauta publicitaria oficial a la revista Fierro (segunda época), editada por el diario Página/12, desde su primer número de 2006 hasta el final del segundo mandato de Cristina Fernández de Kirchner en diciembre de 2015; b) el portal Historietas Nacionales, publicado como suplemento de la agencia de noticias estatal Télam entre 2011 y 2016, espacio en el que se publicaron, con frecuencia semanal, numerosas series de autores argentinos; el "proyecto Télam" implicó el solapamiento entre el campo de la historieta, el campo del Estado y el campo del periodismo (Von-Sprecher, 2012, p.24) que tuvo lugar durante el kirchnerismo; c) el apoyo simbólico y económico del Estado, en sus diferentes niveles nacional, provinciales y municipales, a festivales y convenciones de historieta y otros eventos afines, algunos de ellos festivales anuales de alcance internacional, como el caso del Crack Bang Boom, de la ciudad de Rosario, y el festival Comicópolis, en Buenos Aires, que, luego de cuatro ediciones (2013, 2014, 2015 y 2017), fue discontinuado por falta de apoyo oficial, teniendo una última edición en 2017 ; d) la realización de concursos, como el caso del Premio Centro Cultural de la Memoria Haroldo Conti, dependiente de la Secretaría de Derechos Humanos de la Nación, que contó en 2014 con la categoría "historieta"3; e) la consagración oficial del autor Héctor Oesterheld y de su obra cumbre, El Eternauta (realizada entre los años 1957-1959 con coautoría de Solano López), a través del ingreso del título de ciencia ficción en el canon de la narrativa argentina; ese gesto implicó la inclusión del cómic como material de lectura recomendada en las escuelas públicas secundarias del país, acompañado de actividades pedagógicas que planteaban desde la política partidaria kirchnerista el concepto oesterheldiano de "héroe colectivo"; f) la realización de Continuará..., un programa de televisión conducido durante cinco temporadas por el escritor, guionista y crítico del medio, Juan Sasturain, dedicado al análisis y la divulgación de la historieta argentina en el canal de televisión estatal Encuentro.

3 Desde este enlace puede accederse a más información sobre el Premio Haroldo Conti: https://www.nuevaciudad.com.ar/notas/201501/17583-el-premio-haroldo-conti-ya-tiene-sus-ganadores.html

Perspectivas de la Comunicación - Vol. 14 - No 2 - 2021 - pp. 195-231

Universidad de la Frontera - Chile 
2) En el Uruguay, la política de fomento a la historieta durante el gobierno del Frente Amplio (2005-2020), se materializó a través del Fondo Concursable para la Cultura, dependiente del Ministerio de Educación y Cultura (MEC). El Fondo Concursable es una convocatoria pública anual dirigida a artistas y hacedores de la cultura, para postular proyectos artísticos culturales que son evaluados por jurados externos al citado Ministerio 4 del Gobierno nacional. En este esquema, numerosos proyectos historietísticos han sido publicados con el apoyo y financiamiento público. Damos dos ejemplos que se inscriben en el género narrativo tratado en este trabajo: las ya citadas Zitarrosa (Santullo - Aguirre, 2012), serie que apela al registro de anecdotario, y Tupamaros: La Fuga / 1971 (Roy Leguisamo y Lauri Fernández, 2015), ficción histórico-política que relata cómo era la vida en prisión de los presos políticos que integraban la guerrilla urbana uruguaya, mientras preparaban su fuga del Penal de Punta Carretas.

Asimismo, el Estado uruguayo brinda infraestructura y apoyo oficial para eventos culturales. El caso más importante es el de Montevideo Cómics, convención de historietas surgida en 2002, auspiciada por el Gobierno y realizado anualmente en sitios pertenecientes al sector público como el Auditorio Nacional del Sodre (MEC, Gobierno del Uruguay) y el Centro Cultural España (Gobierno de España). También podemos mencionar que el municipio montevideano brinda espacios para que editores, libreros y autoeditores puedan acercarse al público y ofrecer sus producciones en la Feria Ideas+, situada en el parque Rodó de Montevideo $^{5}$. Por otra parte, existe desde hace varios años, un Conglomerado Editorial del Uruguay, que surgió por iniciativa del área Cultura del $\mathrm{MEC}^{6}$. Lo integran la Cámara del Libro Uruguaya, la Casa de los Escritores, la Cámara de Revistas, la Cámara de Diarios y Periódicos, la Cámara de Editores Independientes, la Asociación de Libreros e Imprenteros y la Asociación Uruguaya de Creadores de Historieta (AUCH). El Clúster que vela por los intereses del sector editorial del país oriental. A través de la AUCH, que cuenta actualmente

4 Información obtenida en el siguiente enlace que lleva al portal del MEC del Uruguay: https://cultura.mec.gub.uy/innovaportal/v/1983/8/mecweb/fcc---fondo-concursable-para-la-cultura?leftmenuid=1983

5 Para mayor información sobre el Espacio Feria Ideas+, se puede acceder a este enlace: https://www.montevideo.com.uy/Tiempo-libre/Espacio-Feria-Ideas--en-el-Parque-Rodo-uc290323

${ }^{6}$ Desde este enlace que direcciona al apartado "Conglomerados Creativos" de la página del Ministerio de Educación y Cultura del Uruguay, puede accederse a información sobre el Cluster Editorial del país vecino: https://www.mec.gub.uy/innovaportal/v/4364/8/mecweb/conglomerado editorial?3colid=4363 
con medio centenar de integrantes, los autoeditores de historieta forman parte de la estructura. Rodolfo Santullo, autor y editor que motiva nuestra investigación y presidente de la AUCH desde 2011, señaló que esta asociación tiene como objetivo la presencia de los catálogos, y por tanto de las publicaciones, en las ferias del libro, "como parte de la producción editorial del país" (Valenzuela, 2011)7. El Cluster editorial uruguayo cuenta con aporte económico gubernamental, que resulta fundamental para cubrir gastos administrativos y logísticos de la AUCH.

Consideramos que las políticas públicas de fomento a la actividad historietística, si bien fueron diferentes en uno y otro país, incentivaron la realización de productos ficcionales que han sabido releer y discutir hechos del pasado en función de las disputas sociales políticas del presente. Asimismo, se generaron experiencias de colaboración creativa y editorial entre autores y autoras de ambas orillas del Río de la Plata, como así también espacios de circulación y de lectura compartidos. En ese universo de obras ubicamos dos historietas históricas que la dupla formada por el guionista uruguayo Rodolfo Santullo y el dibujante argentino Dante Ginevra produjo dentro de un período particular de la revista Fierro. Su propio director, Juan Sasturain, en la editorial que abre el número 55 de la publicación (mayo de 2011), destaca que "cierto tipo de reflexión / alusión política (incluso históricopartidaria) se ha ido manifestando en las páginas de Fierro en los últimos tiempos”, y agrega que, "más precisamente: las referencias pasan por el peronismo en cualquiera de sus formas y experiencias" (Sasturain, 2011, p. 4). La muerte del ex presidente de Argentina, Néstor Kirchner, en octubre de 2010, es un hito a partir del cual "fue creciendo la presencia de la política -o del peronismo, como decía Sasturain-, por lo menos en la zona de la temática de las nuevas historietas de la revista" (Berone, 2012, p. 59). Malandras y Tacuara, publicadas entre 2010 y 2012, son expresión de esa presencia de la que diera cuenta Sasturain en su reflexión sobre Fierro.

\footnotetext{
7 Enlace que nos lleva a información publicada en el sitio Cuadritos, Periodismo de Historieta, por Andrés Valenzuela, que versa sobre el surgimiento de la Asociación de historietistas uruguayos: https://avcomics.wordpress.com/2011/05/18/7826/
}

Perspectivas de la Comunicación - Vol. 14 - No 2 - 2021 - pp. 195-231

Universidad de la Frontera - Chile 


\section{Método y marco analítico}

Partimos del supuesto teórico según el cual las historietas históricas producen sentido a partir de acontecimientos y actores cuyas propiedades y características centrales ya han sido configuradas en discursos fuertemente marcados por su función referencial y en tiempo pasado, en especial por el discurso de la historiografía, aunque también por el discurso de medios de comunicación masiva (Berone, 2018, p.41).

Centrándonos en nuestro caso de estudio, y siempre según Berone (2018, p. 41), la NHHR supone una indagación narrativa de aspectos del problema ético e histórico de la decisión (o de la decisión como problema) en relación con cómo se deciden los acontecimientos y, también, los sujetos. En este sentido, podemos dar cuenta de una naturaleza siempre conflictiva de las relaciones de la historieta con los signos puestos bajo regímenes de lo indicial y lo simbólico. Al contrario de la fotografía -un mensaje aparentemente sin código, que establece una relación de analogía pura con su referente-, la historieta es un código sin mensaje verista (Masotta, citado por Berone, 2020, p. 25), siendo su iconicidad de segundo grado: "llega a la representación de sus objetos, a través de las representaciones que de ellos ya han hecho otros discursos sociales (es decir, la historieta no puede ser otra cosa que arte pop)" (ibíd.). Umberto Eco (1984), en su “Lectura de Steve Canyon”, señala que la naturaleza del lenguaje de la historieta es esquemática (p. 280), pues basa su discurso en la reproducción pautada de estereotipos, plasmados en fórmulas narrativas y gráficas. La historieta no oculta su carácter de construcción, y es ese espesor visual de su discurso lo que la enfrenta a los problemas de la representación de lo real histórico. Al respecto, los “documentos" y "monumentos" le aportarían a la historieta la iconicidad (Berone, 2020, p. 26), es decir, la capacidad del dibujo "de parecerse a los motivos que representa" (McCloud, 2016, p. 27). Mientras los “documentos” históricos poseen un carácter indicial o metonímico, pues consisten en distintos tipos de contenidos que prueban determinados acontecimientos y personas que han participado en ellos, los “monumentos" son objetos públicos visibles que representan o conmemoran hechos y personajes históricos, poseen un valor abstracto o metafórico, y suelen tomar el carácter de símbolos de un lugar por una determinada comunidad. ${ }^{8}$ No obstante, una vez que documentos y monumentos están instalados en la

\footnotetext{
8 Así, vemos cómo los monumentos ecuestres dedicados a Manuel Belgrano situados en el noroeste argentino detentan una importancia (en tamaño, ubicación) mayor a la de cualquier otro prócer -con la excepción del monumento a Martín de Güemes
} 
superficie de la historieta, constituyen rupturas o "momentos excepcionales de un discurso que los utiliza para generar sus propios efectos" (Berone, 2020, p. 26). En el caso de la historieta histórica, la reproducción de ciertas imágenes de lo real histórico, con un aceptable nivel de semejanza o mímesis, funciona como "prueba" o huella de ese pasado. La ruptura viene dada por el cambio en la paleta de colores o en el estilo de dibujo (que se vuelve más verista) o en el tipo de grafía que reproduce un discurso documental (por ejemplo, un recorte de periódico con imagen fotográfica incluida relacionado con el hecho tematizado en la narración).

Si la nueva historieta histórica rioplatense no puede ser icónica de los procesos que representa, es decir, no puede acercarse a la veracidad -como es el caso del discurso de la Historia-, ¿dónde radica el núcleo de este género tan importante en términos de producción en la historieta contemporánea?

Berone nos indica que el núcleo de la NHHR radica en el testimonio, un tipo discursivo cuyo valor proviene de crear un objeto histórico, pero afectado siempre por de algún modo por la subjetividad que lo señala. Entonces, el núcleo definitorio de este género reside en su dimensión testimonial, es decir, su modo particular de dar testimonio y de concebir la articulación entre subjetividad e Historia. Berone (2020, p. 29) se pregunta: “¿De qué dan testimonio estas historietas, en relación con el trabajo social de elaboración de una memoria histórica?”. Estas historietas están motivadas por una vocación política, un intento de sentar posición leyendo el presente a partir de una interpretación del pasado, y operar una relectura del pasado a partir de un particular presente. Señala Berone al respecto:

(...) si hablamos de "nueva historieta histórica", en estos momentos, es para referirnos a la insistencia regular de una intención política: la intención de pensar siempre los "eventos" de la ficción por su doble remisión, en el cruce permanentemente evocado entre pasado y presente, del que carecerían prácticamente todos los posibles ejemplos rescatados de la "historieta histórica" tradicional. (Berone, 2020, p. 22-23)

en Salta-, y asimismo una relevancia mayor a la de otros monumentos al creador de la bandera argentina situados en el resto del país. Las sociedades de las provincias norteñas le rindieron -y rinden- ese tributo a Belgrano en reconocimiento a su obra política y militar del período independentista. 
Para el autor, si el testimonio no está del lado de la verdad sino de la experiencia o la subjetivación de lo real, estas narrativas gráficas contemporáneas logran introducir una "falla" o un "resto", corporal e inalienable, entre la subjetividad y la Historia. La construcción del testimonio no se logra sino con la introducción de "figuras subalternas -siempre borrosas, incidentales y secundarias en la historieta histórica 'tradicional'-” (Berone, 2020, p. 31), que en la NHHR aparecen colocados en el centro del escenario de la ficción. En la historieta histórica, y más precisamente en el género NHHR, el lector/receptor es obligado a instalarse narrativamente en el presente de las instancias o hechos desarrollados en el relato, y a partir de ese rasgo de enunciación se abre espacio a un "excedente de lo real" que al discurso historiográfico le costaría mucho más aprehender o representar. La materialización de ese "excedente de lo real" en la narración se logra de manera verosímil más que verdadera, dada la autonomía, con respecto al signo, del referente representado. Los procedimientos de construcción testimonial pueden ser pensados a partir de la categoría de operaciones discursivas recordatorias o constructoras de memoria social (Savoini \& Siragusa, 2017, p. 19). Siguiendo el modelo teórico de Berone, en este trabajo exploraremos dos tipos de experiencias construidas a través del testimonio:

1) En primer lugar, estas nuevas historietas históricas señalan y posibilitan una experiencia definida de la materialidad subjetiva del ícono: el dibujo.

\footnotetext{
En la historieta tradicional, el estilo de dibujo, organizado y estandarizado generalmente a partir de la oposición binaria entre dibujo serio (“dibujo realista”, o estilo ilustración) y dibujo caricaturesco (o “dibujo humorístico”), lo que hacía era pautar y estipular un modo de lectura: el modo de lectura que era necesario asumir respecto de los hechos representados. Como tal, una historieta histórica "tradicional" difícilmente podía sostenerse en un estilo de dibujo caricaturesco -hasta que llegó Maus, de Art Spiegelman. (Berone, 2020, p. 29-30)
}

La caricaturización es, según McCloud (2016), una forma de amplificación por medio de la simplificación. Al caricaturizar, no necesariamente se procura un efecto cómico o humorístico. Según Gombrich, la caricatura ha sido expresionista siempre y no ha de ser exclusiva ni necesariamente humorística. Para el autor, el trastrocamiento de las relaciones de semejanza se orienta a modificar la percepción de las cosas en pos de revelar alguna cualidad de los personajes, un sentimiento o un pensamiento (Gombrich, 1995, p. 564). En los distintos géneros de la historieta de aventura, el resaltado de ciertos detalles físicos de los personajes o la modificación de un detalle del ambiente, permite que las acciones signifiquen más que si el dibujo se ciñera al estilo realista convencional. "Al reducir una 
imagen a su 'significado' esencial, el dibujante puede amplificar dicho significado de una manera que no está al alcance del dibujo realista" (McCloud, 2016, p. 30). En una historieta de dibujo realista donde sean introducidos elementos de caricaturización, la narración gráfica se verá enriquecida por rasgos que, tradicionalmente, no están asociados al grafismo clásico o verista. Siguiendo el esquema teórico y analítico de Berone, nos preguntamos: ¿De qué dan testimonio los estilos de dibujo de las nuevas historietas históricas de las tierras del Plata? Esa cuestión la dilucidaremos en un breve análisis sobre dos historietas guionadas por Rodolfo Santullo que hemos seleccionado como parte de nuestro corpus.

2) El problema de la actuación histórica, una dimensión relacionada con la performance del actor que tiene que componer la identidad del personaje monumental. Tanto en el cine como en series televisivas, novelas literarias y en la historieta, resulta clave el modo en que el personaje encarna una figura histórica, si resulta creíble o no, más allá de la veracidad de los hechos narrados (las licencias dramáticas son comunes en narrativas ficcionales de tema histórico).

\footnotetext{
En la historieta, de lo que se trata es que se abre también, para los documentos y los monumentos de la historiografía, la dimensión de la actuación. En el sentido de que la figura, monumental o documental, es puesta en serie o en secuencia gráfica con otras actuaciones: la de los "comparsas" (si se quiere) de la memoria histórica; aquellos/as que la historieta necesita recuperar de la noche y de la bruma de los discursos sobre la historia, para hacerlos actuar en la página. (Berone, 2020, p. 31)
}

En las historietas analizadas aquí, la experiencia de la actuación histórica se modeliza a través de distintos recursos testimoniales, que pueden funcionar a partir de la introducción de personajes que interactúan con los artefactos de memoria (Mendoza-García, 2014) tales como monumentos y documentos -sin perjuicio de que el "comparsa", puesto en (inter)acción con la figura monumental, pueda ser a su vez otra figura histórica, un personaje con referencia en el mundo real-, o de aquellas actuaciones que son en cierto punto referenciales de un personaje real -por poseer o encarnar, más o menos ambiguamente, rasgos de la figura histórica- aunque se trate de un personaje ficcional.

Concebimos a la NHHR como un megagénero pues, desde diferentes fórmulas o dispositivos narrativos (el policial gangsteril, el drama político, el anecdotario con tintes biográficos) explota la condición de la historieta como medio expresivo a través del cual se construye memoria y se revisa el pasado. Las narraciones gráficas que componen nuestro corpus de 
análisis dan sentido a acontecimientos históricos en relación con ciertas condiciones de producción -entre ellas, un imaginario social sobre el pasado construido en un particular presente y el aludido proceso de ampliación del espacio de lo decible y de lo visible que tuvo lugar en las últimas dos décadas a partir de una serie de las políticas públicas y culturales impulsadas por los Estados nacionales de ambas orillas del Plata-.

\section{Resultados}

\subsection{Malandras de Fierro}

En el número 45 de la revista Fierro, publicado en julio de 2010, salió un unitario de ocho páginas, denominado "Malandras", firmado por Rodolfo Santullo en guion y Dante Ginevra en dibujo. Con el paso de los meses, cada número de la revista traía una nueva entrega aparentemente autoconclusiva e independiente, de los mismos autores, que iba tejiendo vínculos más o menos soterrados con aquel primer episodio. Pese a no compartir un título común que los aglutinara, con el tiempo esa sucesión de capítulos dio lugar a una compleja trama narrativa condimentada, en dosis equilibradas, con política, mafias, corrupción policial, delincuencia callejera, tango, cabaret, amores furtivos, golpismo militar y su contraparte, la lealtad, todo ambientado en el arrabal porteño de mediados del siglo XX.

En el libro que recopila la serie, publicado por la editora porteña Historieteca (Santullo \& Ginevra, 2014), el primer capítulo se retituló "Mataderos 55”, y su nombre original (el que salió en Fierro) terminó dando el nombre a la novela gráfica: Malandras. El cambio nominal nos indica el raro origen editorial de esta historieta, que devino serie a partir de la creciente aceptación de los lectores, la habilidad de sus creadores para construir a partir de episodios cortos una compleja historia de trasfondo político forjada, y el buen ojo del editor de Fierro.

¿De qué trata este cómic que incluimos dentro del megagénero NHHR? La historia se sitúa en el barrio de Mataderos, Buenos Aires, en junio de 1955, y tiene el eje central de las acciones en "Calzada", un ladrón de poca monta que fortuitamente ha descubierto a un grupo de militares conspirando contra el Gobierno y la propia vida de Juan Domingo Perón, y por tal motivo es perseguido. A medida que van sucediéndose sus 12 episodios, la inclusión de otros personajes, algunos de ellos con rasgos identificables con personas públicamente conocidas, va complejizando la trama. 
A continuación, daremos cuenta de operaciones de reconstrucción del pasado histórico a partir del dispositivo del testimonio, que podemos identificar en esta historieta.

En relación con el dibujo, no se observa un desarrollo en los fondos, aunque sí un buen apoyo documental: las edificaciones, las modas, los vehículos, los interiores del cabaret y el bolichón con su banda sonora de tangos y milongas (ver Figura 1). La atmósfera de Malandras da una sensación de precisión temporal de los hechos narrados, sin dejar a un costado la expresividad en el trazo y la composición en las que se destaca Ginevra.

Figura 1. Malandras, de Rodolfo Santullo y Dante Ginevra

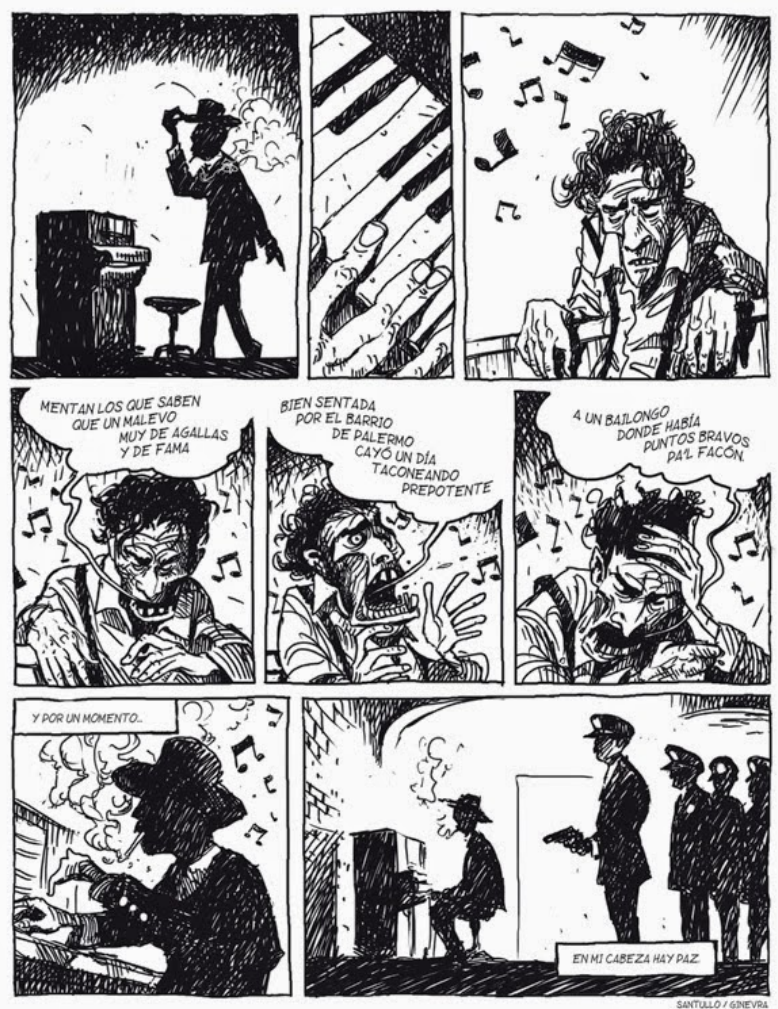

Fuente: SANTULLO, GINEVRA, Malandras, 2014, p. 64. Acervo del autor.

En la composición de los personajes, abundan "nombres propios gráficos” (Reggiani, 2012) -de aquí en más, NPG-: personajes con rasgos identificables con personas públicamente conocidas. Figuras que remiten a un referente real, reconocibles inmediatamente por cualquier lector argentino de mediana edad, pero cuya identidad ficcional no coincide con la 
del referente real. La inclusión de NPG en la historieta aporta un guiño de complicidad al conocimiento del lector y funciona en la narración con una intención política.

Los personajes NPG son acompañados de la estereotiparían y, a partir de un particular estilo de dibujo, de la caricaturización. Esta composición gráfica del personaje constituye una modalidad de las actuaciones históricas otras, los "comparsas" de la memoria histórica (Berone, 2020, p.31). El grado de identidad con un referente real -identidad no sólo en aspecto físico sino también respecto al nombre, la profesión, el carácter o la personalidad-, va a definir qué intensidad tendrá cada personaje NPG. Veamos ejemplos.

Ya desde el primer episodio, Malandras plantea una disputa territorial entre dos bandas mafiosas por el control del barrio porteño de Mataderos. Allí, los mafiosos italianos llevan ropa y rasgos que acusa su identidad étnico-nacional (trajes con rayas, sombreros, bigotes), mientras que en los rusos se realza su origen por algunos giros lingüísticos y, también, por el aspecto físico. Sobre todo, en uno de los personajes cuyas facciones y rasgos remiten al místico Rasputín. Esas señas de identidad, en algunas viñetas, son exageradas, caricaturizadas en pos de una ganancia de efecto expresivo (ver Figura 2). 
Figura 2. Primera página del primer capítulo de Malandras en formato novela gráfica.

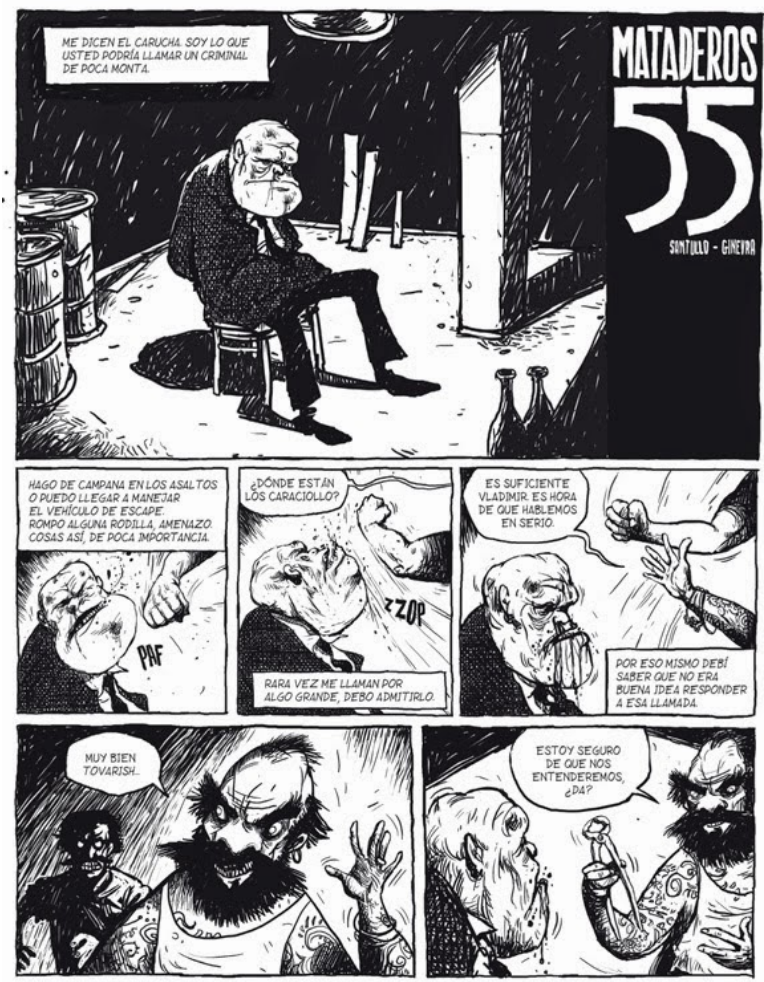

Fuente: SANTULLO, GINEVRA, Malandras, 2014, p. 5. Acervo del autor.

Otro NPG, de naturaleza distinta, lo encontramos en dos personajes secundarios, de aparición ocasional (en el tercer episodio, "Una noche cualquiera", y el noveno, "Che Bandoneón”). Son un par de amigos clientes del cabaret, una de las locaciones centrales de las historias que Santullo y Ginevra componen en Malandras. Esos personajes son identificables con dos autores canónicos de la historieta argentina, Alberto Breccia y Héctor Oesterheld -a éste último nunca se lo nombra-. En particular, el NPG de Breccia, llamado "Alberto" por su amigo, es retratado como un matarife cuya vocación profesional confiesa a la alternadora del sitio, la bellísima "Paloma": es dibujante y cuenta "historias con imágenes”, pero al tener las manos estropeadas, no consigue explotar el potencial artístico. Sin mediar comercio sexual, Alberto encuentra una solución inesperada a su problema cuando Paloma le obsequia un ungüento de propiedades mágicas para sus heridas. Lo interesante es el guiño al lector avezado en historieta argentina clásica, pues una serie de características del aludido personaje coinciden con datos biográficos del propio Alberto Breccia real, desde su crianza en Mataderos, su dura vida laboral como tripero y el deterioro 
de su salud y, principalmente, de sus manos (Figura 3). Y la época también aporta verosimilitud a la improbable secuencia: a mediados de los años 50, Breccia y Oesterheld ya se eran mutuamente conocidos en el ámbito profesional de la historieta, y no faltaría mucho tiempo para que el dibujante se incorporara a Frontera, la editorial fundada por el consagrado guionista.

Siguiendo con el recurso a los NPG, encontramos un personaje secundario, encarnado por el jerarca militar que encabeza la intentona golpista, el hecho vertebral de la historia. El rostro del "Teniente" no es sino el del represor argentino Emilio Eduardo Massera, miembro de la junta militar de Gobierno entre 1976 y 1981 durante la última dictadura. Aquí la precisión referencial es, al igual que con "Alberto", compleja, tanto por lo verbal como por la elección gráfica: el nombre del personaje ("El Teniente”) y sus posturas y opiniones políticas lo hacen identificable a un Massera joven, mientras que sus rasgos físicos remiten directamente al genocida. No obstante, su inclusión en la historia funciona como una alusión de tipo anacrónico con respecto al presente del relato: la referencia al componente ideológico reaccionario, clasista y racista tiende una línea de continuidad entre dos periodos históricopolíticos traumáticos del país, a saber, la autodenominada "Revolución Libertadora" iniciada en 1955 y el autodenominado "Proceso de Reorganización Nacional” de 1976. La construcción gráfica y narrativa del personaje del "Teniente”, y la caricaturización de la que es objeto (exageración de rasgos faciales durante escenas de claro enojo del personaje, como es apreciable en la Figura 4), abona al clima de tensión y de odios políticos y de clase. A partir de estas operaciones, la experiencia del '55 se propone en la ficción como un momento bisagra donde queda plantada la semilla político-ideológica antipopular, antidemocrática y antiperonista que luego se replicaría en períodos políticos subsiguientes hasta el advenimiento de la última dictadura cívico militar en 1976 (entre el derrocamiento de Perón y el retorno del peronismo al poder, hubo en Argentina dos dictaduras cívico-militares, dos gobiernos constitucionales elegidos bajo la proscripción del partido peronista y un gobierno no constitucional controlado por los militares). Es clara entonces la intención política del uso del NPG y del recurso a la caricatura en una historieta inscripta en los géneros de aventuras, precisamente una historieta histórica. 
Figura 3. Tercer episodio de Malandras, "Una noche cualquiera".

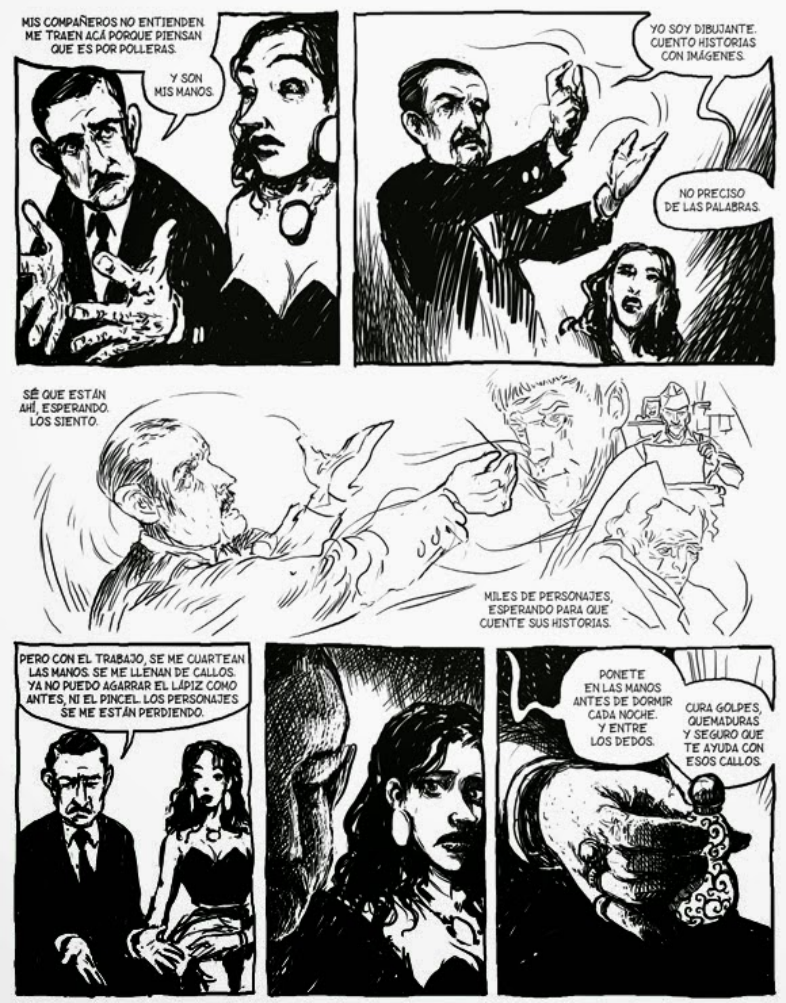

Fuente: SANTULLO, GINEVRA, Malandras, 2014, p. 17. Acervo del autor.

Otro acierto del guion de Malandras es la manera en que documentos y monumentos interaccionan con estos otros personajes menores, si se quiere, los "comparsas" de la historia (Berone, 2020, p.31). Por ejemplo, la presencia de Perón en la serie es permanente, aunque nunca aparece físicamente. Habita en diálogos de otros personajes, documentos, en el grito de guerra de Calzada, el asaltante de colectivos (escapa con su botín al grito de "iViva Perón, carajo!", o, en episodio "Che Bandoneón” cuando le confía al dueño del cabaret que en lo de Laramuglia había "un montón de milicos planeando bajar al General”) y en retratos en paredes hogareñas -como, por ejemplo, en la casa del “Alférez Atilio Guzmán”, joven militar leal al Gobierno y también personaje clave en la historia-. En algunos diálogos, incluso, se omite mencionar por su apellido al líder justicialista, ya sean partidarios o enemigos quienes se refieran a él. Sus partidarios lo llaman "el General”, y sus detractores, en particular el líder militar golpista, lo mencionan como "este hijo'eputa”. La omisión del nombre propio de la máxima figura histórica contiene, pues, más de un sentido, desde el odio hasta el afecto. En 
este último caso, los personajes que más refieren a Perón son el propio el ladrón "Calzada" y el "Alférez Atilio Guzmán".

Figura 4. Página del episodio “Che bandoneón”, Malandras.

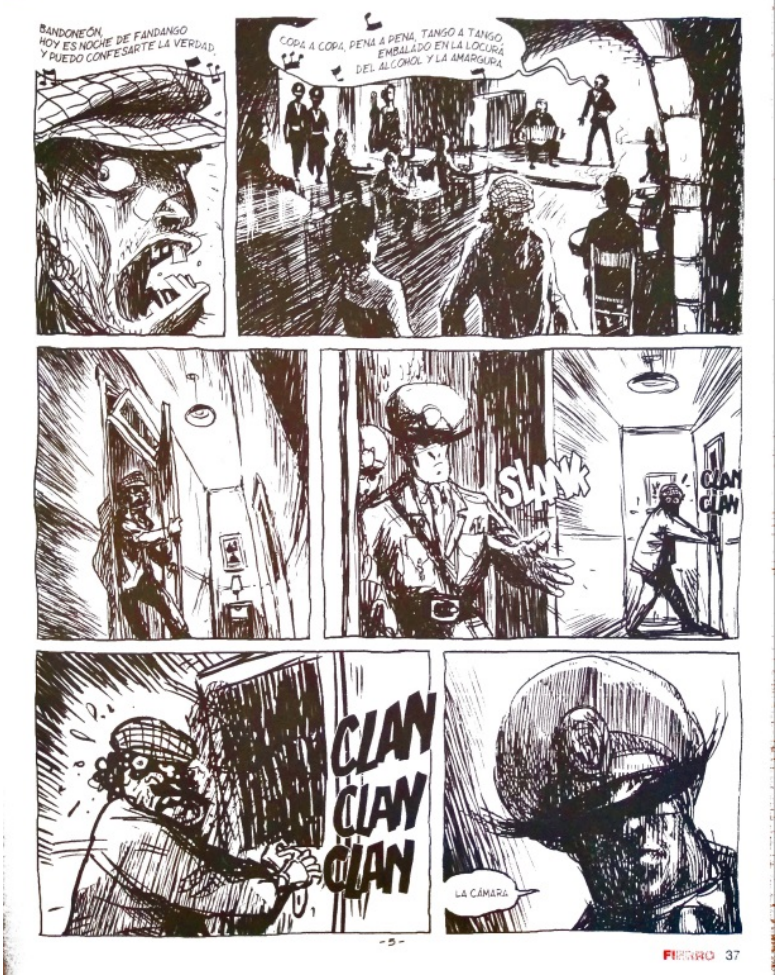

Fuente: SANTULLO, GINEVRA, Malandras, 2014, p. 53. Acervo del autor.

Asimismo, esa omisión o evitación del nombre de Perón recrea de modo verosímil el clima de miedo y tensión política reinante, que progresivamente va pasando de un estado latente a otro patente en la historia construida por Santullo y Ginevra. La operación de construcción de clima político de época, asimismo, se observa en otros pasajes de la historia, como el homenaje que los autores rinden a los dos citados grandes maestros de la historieta mundial. En una conversación en la mesa del cabaret, durante el noveno episodio titulado "Che Bandoneón", "Alberto" (Breccia) comenta a su amigo, un personaje no identificado nominalmente pero claro NPG de Héctor Oesterheld, que unos militares le pidieron que dibuje los planos de Plaza de Mayo. En la escena puede hasta respirarse un aire enrarecido, por momentos opresivo que, si bien los personajes no llegan a distinguir netamente, lo intuyen, algo raro huelen, en especial el propio Oesterheld, quien, mirando para los 
costados, le ruega a su amigo "Alberto" sigilo y discreción al hablar del tema.

La otra figura histórica de la historieta, cara a la historia misma del justicialismo, es el General Franklin Lucero. El mismo, en carne y hueso, hace finalmente su aparición en el interior de la Casa de Gobierno durante el último episodio, "El bombardeo". Lucero recibirá una información muy sensible que resuelve la intriga tramada a lo largo de la serie: uno de los miembros más subordinados del clan de malandras "Caracciolo" y que no está precisamente acompañado de la buena suerte, el ya mencionado "Carucha", da aviso a Lucero de una inminente conspiración golpista: el bombardeo e intento de asesinato contra el mismísimo "General", "el otro General". La información verbal dada por "el Carucha" adquiere veracidad cuando Lucero recibe del malandra un documento que da testimonio de lo revelado: la fotografía, tomada por el Álferez Atilio Guzmán en la Quinta de Laramuglia durante la reunión secreta de golpistas, y que Guzmán entregara a Calzada antes de ser acribillado por éstos. La escenificación del diálogo entre "el Carucha" y Lucero -que más que diálogo es un interrogatorio no sin apremios ilegales-, intercala imágenes de aviones sobrevolando la Casa Rosada, arribando a su objetivo. El efecto de simultaneidad y dinamismo de las acciones se refuerza en la puesta en página: las viñetas inferiores, ocupando todo el ancho de las páginas, se componen de imágenes de los aviones prontos a atacar. La gráfica de Ginevra adquiere fuerte carga indicial, pues en esa recreación del bombardeo a Plaza de Mayo del 16 de junio de 1955, parece basarse en documentos de la época, más precisamente fotografías periodísticas. El humanismo del relato devela y su vez contrasta el impulso genocida del agresor: una sucesión de viñetas nos presenta imágenes de transeúntes, personas comunes como una madre con un bebé, que en medio de su cotidiano se dan cita, fortuitamente, en un momento aciago de la Historia latinoamericana que tuviera su epicentro en plaza de Mayo (Figura 5). 
Figura 5. Página del episodio final de Malandras, "El bombardeo”.

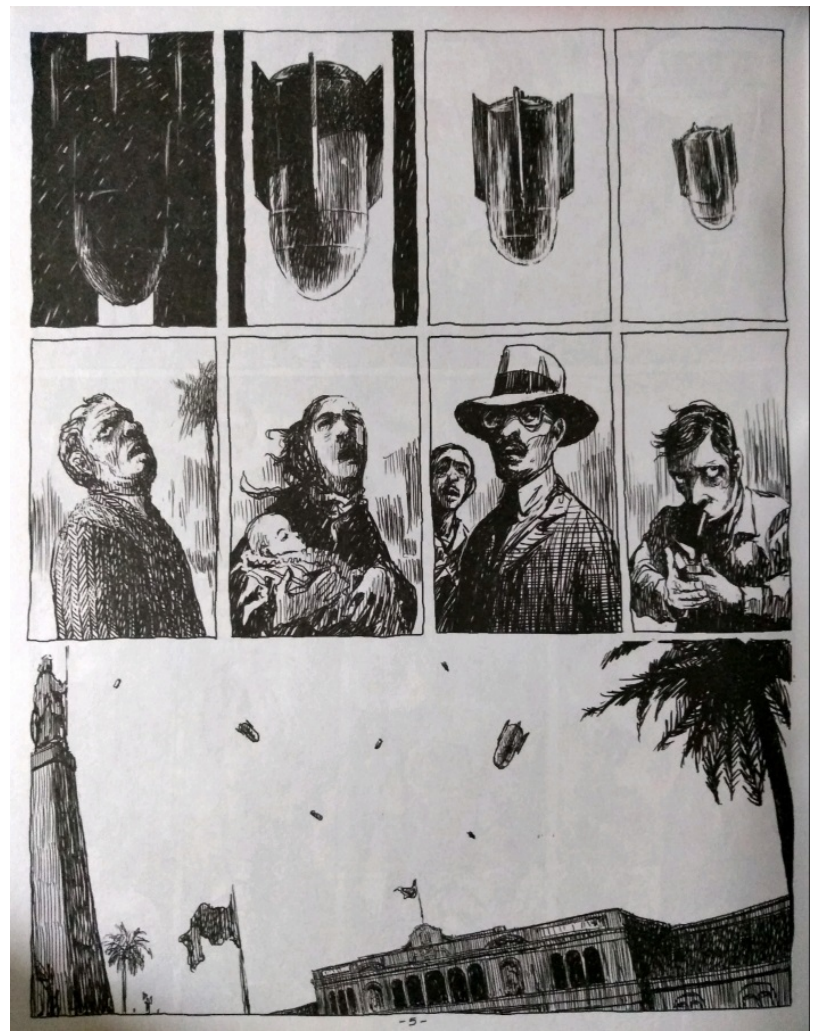

Fuente: SANTULLO, GINEVRA, Malandras, 2014, p. 77. Acervo del autor.

Para finalizar, rescatamos otra secuencia que se presenta promediando la historia, donde las figuras históricas son puestas en fase con los "comparsas" de la memoria histórica (Berone, 2020, p.31). El episodio "El Reporte" presenta una estructura narrativa recurrente en varios capítulos de Malandras y que involucran a personajes distintos: hay un apoyo en la reproducción textual -en una tipografía que imita a la de una antigua máquina de escribirde una carta que el Alférez Atilio Guzmán, joven militar leal a Perón, envía al General Lucero para anoticiarlo de la conspiración tramada en contra del Presidente. En una viñeta de plano abierto, en la que se sitúa al alférez en su habitación sentado frente a su Olivetti, se observa pendiendo de la pared un monumento que también hace las veces de documento de época: el retrato de Perón y Evita. En un pasaje del episodio, el contenido de la carta reproducido en textos de apoyo combina con imágenes ilustrativas del origen social humilde del Alférez, construcción narrativa que explicaría su adhesión incondicional al peronismo (Figura 6). En "El Reporte" se reproduce el malentendido o accidente necesario (Bourdieu, 1995) que 
motoriza la historia y que explicarán los hechos que tendrán lugar en el episodio octavo, "El agente del General del General Lucero”. El Alférez confunde al ladrón de colectivos Calzada (quien accidentalmente, y por otros motivos, acudiera a la Quinta de Laramuglia) con un agente a quien el General Lucero habría enviado a espiar durante el cónclave de militares conspiradores antiperonistas. En sus cartas -seis en total-, el Alférez Atilio Guzmán describe detalles de cada una de las reuniones en la aludida Quinta de Laramuglia, de las que fue testigo y llegó a tomar registro fotográfico de ellas. Guzmán menciona diálogos entre golpistas, hábilmente reproducidos en el relato, y que tienen como actor central al "Teniente". El reporte escrito en sus cartas, y la fotografía que las respalda en tanto signo indicial, son documentos, ficticios, que anticipan los hechos por venir. No obstante, ciertas circunstancias dadas a conocer en el relato -entre ellas, la lentitud de la oficina de correos del Estado- impiden que esas cartas lleguen a tiempo a su destinatario. El guion logra agilidad y economía narrativa, al trazar en la mayoría de los episodios un hilo argumental que alterna y entrecruza momentos narrativos, y así en una misma viñeta tenemos textos que testimonian acciones que no refieren precisamente a los hechos que expresa el dibujo. 
Figura 6. Episodio "El Reporte", de Malandras.

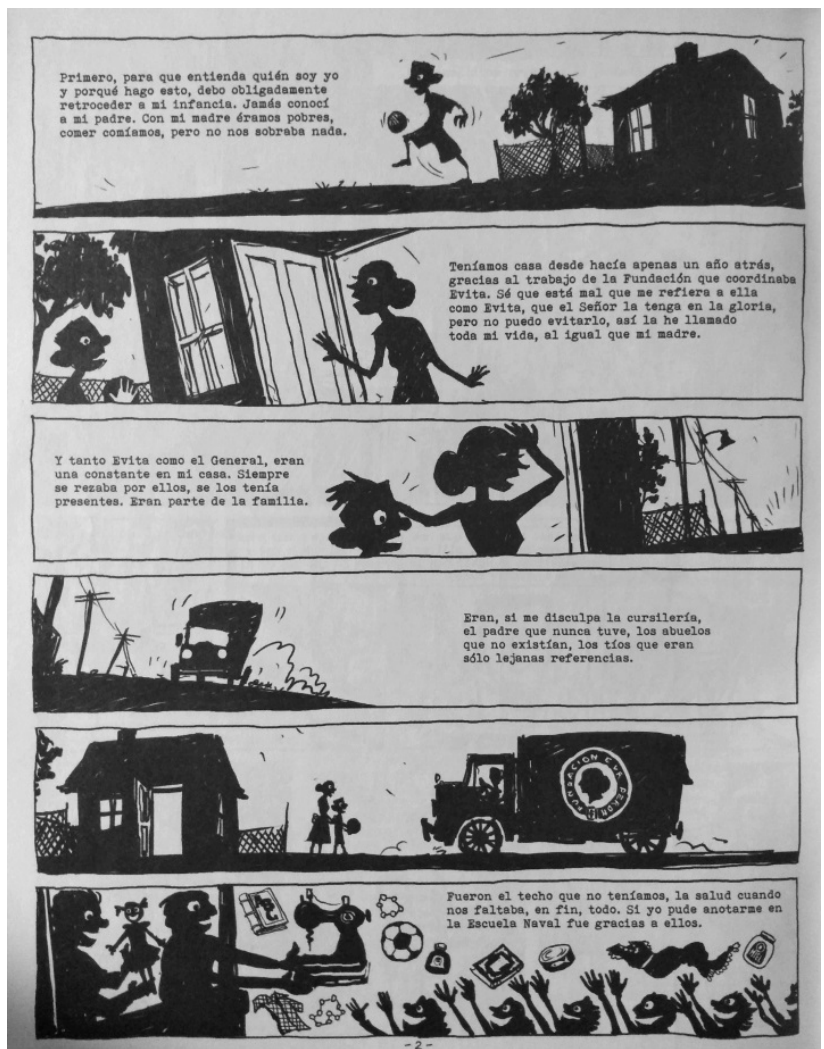

Fuente: SANTULLO, GINEVRA, Malandras, 2014, p. 3o. Acervo del autor.

\subsection{Tacuara: ficción política de época}

Entre los números 65 y 74 de la revista Fierro (de marzo a diciembre de 2012) fue publicada Tacuara. A cada una de sus diez entregas de ocho páginas la encabeza el nombre de la serie y un subtítulo más informativo que literario, anticipativo del argumento: por ejemplo, en el primer episodio, “1. Coraje, disciplina y organización”, se presentan a los protagonistas, Alberto Ezcurra y Joe Baxter, y al grupo que lideran, su misión y objetivos. Nos referimos a la organización política y terrorista Tacuara, operativa en Argentina entre fines de los años 50 y mediados de los 60 del siglo XX. Desde ese primer capítulo esta obra de expresivos dibujos en colores de tonos pastel y de ambientes oscuros, la dupla Santullo-Ginevra perfila las diferencias ideológicas de ambos referentes de la agrupación, y que serán cruciales en el devenir del drama político narrado: Ezcurra es un nazi antiperonista con una visión del mundo monolítica, mientras que Baxter es un nacionalista de perfil más pragmático, abierto a nuevas ideas y afín a causas revolucionarias antiimperialistas. 
El tema político moviliza a los personajes y los pone en situaciones que podemos entender como terrorismo, clandestinidad e insurrección respecto de un orden que no aceptan, y es la cuestión política la que altera sus relaciones. La estrategia narrativa de Santullo y Ginevra establece un equilibrio entre la información del contexto sociopolítico que enmarca las acciones, y el peso dramático que recae logradamente en los personajes principales.

Respecto de este equilibrio, uno de los grandes hallazgos de Tacuara está en la ya aludida inclusión de contexto: a lo largo de sus diez episodios, se recrean conversaciones, anécdotas, discursos públicos, entrevistas a líderes políticos, relatos policiales y periodísticos de la época, los años 6o. En más de uno de esos pasajes de la historieta, estos elementos se incluyen en analepsis o en la presentación de dos hechos ocurridos simultáneamente. En ambos casos, destaca un código visual basado en el cambio de colores - para distinguir dos hechos simultáneos o bien para identificar, dentro de la puesta en página, secuencias del pasado de otras situadas en el presente de la narración. Un ejemplo de este recurso eficazmente utilizado a lo largo de la serie, el del trazado de dos líneas narrativas, diferenciadas en la puesta en página por la ubicación espacial y por los colores de los fondos, lo tenemos en la entrega “2. De secuestros, torturas y represalias”. Esta representación del rapto de Graciela Sirota recrea, en las viñetas superiores y centrales de la mayor parte del episodio, las acciones del secuestro de la joven judía, donde destacan tonos verdes oscuros; mientras que, en la franja inferior de la página, trabajada en fondos rojizos, la secuencia es protagonizada por Ezcurra, en un acto de militancia, donde pronuncia un encendido discurso antisemita ante sus seguidores (Figura 8).

Nos detendremos sobre este episodio que recrea un hecho fundamental de la historia de Tacuara: el bautismo de fuego del MNRT comandado por Baxter y Nell, luego de su ruptura con la facción nazi liderada por Ezcurra. La secuencia del atraco al Policlínico Bancario, que ocupa tres páginas, se introduce como analepsis, un salto hacia atrás en el tiempo narrativo, pues al inicio del capítulo se presenta el crimen ya consumado. La narración integra el relato de la Policía y de la prensa sobre el suceso en la voz de personajes terciarios (policías, un "canillita" que vocea los titulares del diario), instalando así documentos en la superficie de una ficción presta a representar un acontecimiento histórico. La secuencia del asalto es ilustrada en un color diferente al del resto del episodio, cercano al lila claro. Esa variación cromática, sumada al estilo de dibujo difuminado y más ligero de trazos, refuerza la idea de flashblack empleada en la secuencia. El cambio del color lo notamos en otras operaciones 
recordatorias realizadas en la ficción de Tacuara, como el ya mencionado encuentro entre Baxter y Perón en Madrid.

Los documentos escenificados complementan y muchas veces se integran a la historia central y permiten toques de libertad creativa al guionista, quien se muestra sólido en materia de documentación e información histórica y seguro de su oficio de narrar una ficción política e histórica.

Santullo y Ginevra apoyan su trabajo en fuentes documentales. Al ligar a los hechos narrados y a sus protagonistas a un referente real, imprimen a la historieta un espesor indicial más fuerte que en Malandras, la otra historieta bajo análisis. Por ejemplo, en el quinto episodio se presenta un relato policial encanalado en un recorte prensa que informa sobre el asalto al Policlínico Bancario argentino, o en las apariciones televisivas de figuras monumentales como Fidel Castro dando un discurso (episodio “4. Revolucionarios de verdad”, visible en la Figura 7) y figuras públicas de menor monumentalidad, como el propio protagonista de la serie, José Baxter, siendo entrevistado por el periodista Bernardo Neustadt (episodio "7. Prohibidos, amenazados, repudiados”). Las ilustraciones que reproducen con rigor facsimilar los registros periodísticos de la época borronean la frontera entre elementos ficcionales y no-ficcionales (declaraciones, apariciones públicas, hechos criminales adjudicados a la agrupación). Otros ejemplos encontramos en la recreación del asalto al Policlínico Bancario (episodio 5), en el secuestro de la estudiante judía Graciela Sirota (episodio “2. De secuestros, torturas y represalias”), y en el asesinato del joven militante comunista, también de origen judío, Raúl Alterman (episodio 7).

Si bien en largos pasajes del cómic se mantienen conversaciones y discusiones ideológicas y políticas entre los personajes, los apoyos textuales son inexistentes o mínimos, y las viñetas mudas aportan expresividad y agilidad a la acción y pausa entre diálogos. 
Figura 7. Cuarto episodio de Tacuara, de Rodolfo Santullo y Dante Ginevra.

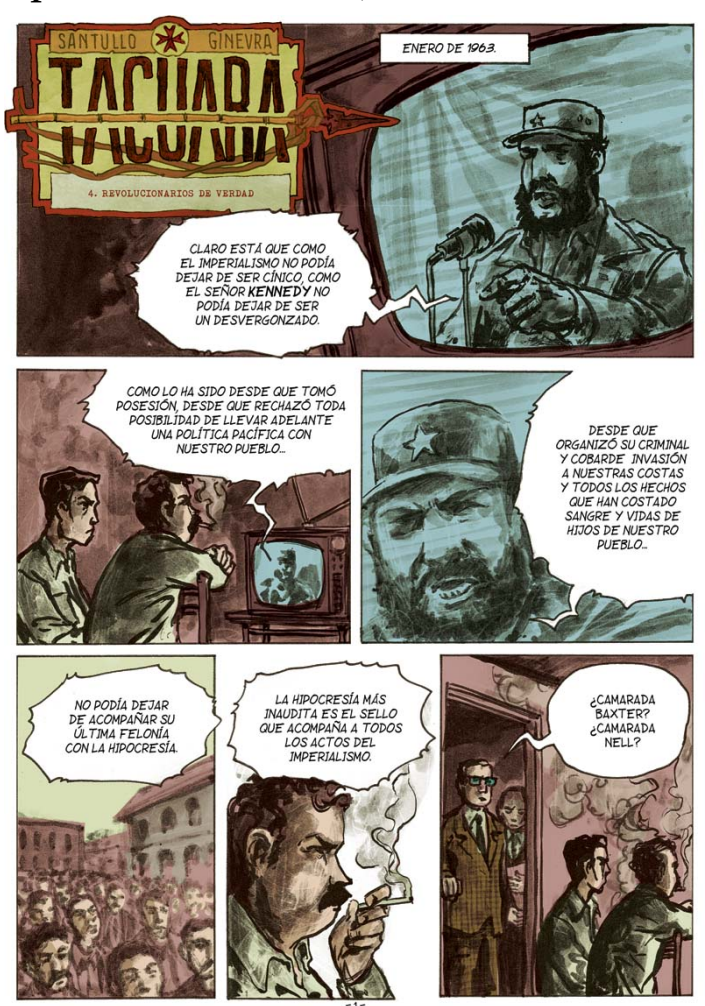

Fuente: SANTULLO, GINEVRA, Tacuara, en revista Fierro $n^{\circ}$ 68, junio de 2012, p. 67. Acervo del autor.

Otro elemento formal, también presente en Malandras- es la recuperación, predicción y reflexión sobre los hechos en la boca de personajes anáforas (Hamon, 1977), recurso que aporta dinamismo a la trama. La función recae principalmente en los protagonistas, aunque en algunos episodios la notamos en personajes secundarios. El episodio “3. La verdad según Ezcurra y Baxter" recrea un reportaje, de existencia real, entre dos periodistas de la revista Mundo Israelita y los líderes de Tacuara. Mientras se dirigen al encuentro, dialogan y hacen un recuento de los hechos criminales que se les atribuye a la organización. Durante la entrevista, que tuvo una existencia real, Baxter y Ezcurra definen los propósitos y principios de Tacuara, y dejan aflorar sus diferencias en torno a la relación que mantendrían con el peronismo. Sobre el final del capítulo, los periodistas sacan conclusiones sobre el encuentro. La tesis de uno de ellos cumple una función predictiva y organizativa sobre el devenir de la historia. Transcribimos un fragmento del breve diálogo: 
- Es como yo te decía. Mucho bla-bla-bla. Mucha palabra rimbombante, mucho discurso. Pero son unos pibes desnorteados nomás. Puro perro que ladra y no muerde.

- No Rogelio... no son perros. Son serpientes. De las venenosas. Y vaya si me temo que van a morder.... (Santullo \& Ginevra, 2012, p.74)

Figura 8. Segundo episodio de Tacuara, de Rodolfo Santullo y Dante Ginevra.

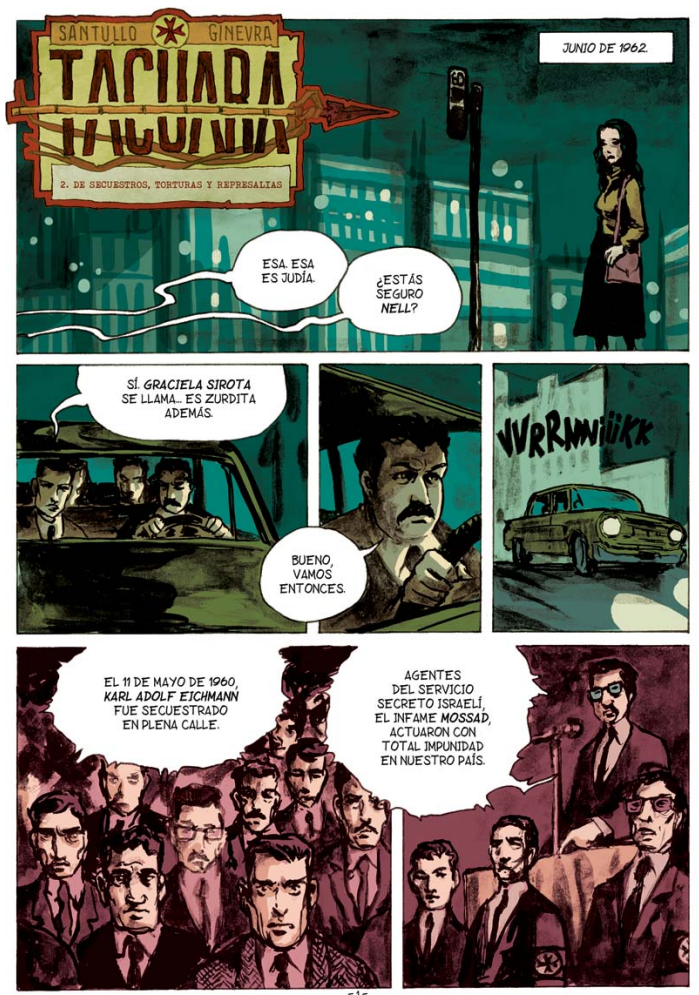

Fuente: SANTULLO, GINEVRA, Tacuara, en revista Fierro $n^{\circ}$ 66, abril de 2012, p. 58. Acervo del autor.

En Tacuara, los nombres e identidades de los personajes principales y prácticamente todos los secundarios remiten a figuras históricas reales, no tenemos NPG como en Malandras. Las figuras históricas, investidas de distintos grados de monumentalidad o significación cultural (Berone, 2020), acaban interactuando o cruzándose, como es el caso del intercambio entre Perón y Baxter -una figura histórica de monumentalidad menor-, o las interacciones entre los protagonistas, y entre éstos y otros miembros de la agrupación Tacuara que se ubican como personajes secundarios. Asimismo, existe en Tacuara un tipo de personaje de monumentalidad doble, por su remisión tanto a la Historia como a la ficción. Analizaremos los ejemplos dados de cada tipología. 
En su octavo episodio, el trabajo de Santullo y Ginevra cruza la monumentalidad de dos figuras históricas, el propio Juan Perón y Joe Baxter. Tanto en esta serie como en Malandras, Perón encarna el monumento histórico por antonomasia. El relato representa un hecho tal vez anecdótico para la historia del peronismo, aunque trascendental en la trayectoria política de Baxter. En la entrevista con Perón (ocurrida en 1964), el dibujo de la escena es evanescente, con colores apagados de tono pastel, logrando efecto expresivo al explotar un hecho cuyo contenido (hablado, tratado por sus protagonistas) es difícil de documentar fehacientemente. El ingreso en la ficción del fundador del justicialismo es irónico pues cuestiona lo que representa su emblema monumental: el General es representado como un líder oportunista que muda sus posiciones políticas de acuerdo con la conveniencia del momento. En el inicio del diálogo con Baxter, Perón expone una postura política de derechas, incluso apoyada en referentes fascistas. Perón revisa su posición luego de que Baxter le hablara de las bondades de referentes revolucionarios de aquel nuevo tiempo histórico, como el chino Mao Zedong. La escena, amén de inspirarse en una anécdota relatada por Baxter, constituye una operación recordatoria (Savoini \& Siragusa, 2014) de un hecho político trascendental de la segunda mitad de los 60: el acercamiento de Perón a sectores de la izquierda revolucionaria en Argentina. Asimismo, en el espacio ficcional de Tacuara no dejar de insinuarse un guiño cómplice al lector medianamente conocedor de la historia política argentina, pues, irónicamente, el relato anticipa el péndulo que el propio Perón -el referente real- dibujó durante sus últimos años de vida. Brevemente dicho: así como el General se acercó a grupos de izquierda durante su exilio, se recostó en la derecha del movimiento peronista una vez que éste volviera al poder en 1973. Las referencias a anécdotas que se presuponen reales, como el comentario de Perón a su secretario, Villalón, tras su entrevista con José Baxter ("Un muchacho fantástico. Parece capaz de hacer él solo la revolución”), refuerza el contraste que se va tramando entre los protagonistas de la serie y anticipa hechos futuros.

Entre los personajes históricos de monumentalidad menor, identificamos a los dos protagonistas de la serie, a lo que se suman otros miembros de Tacuara, como el ultraderechista católico Juan García Elorrio, y José Nell. Este último fundaría junto a Baxter el Movimiento Nacionalista Revolucionario Tacuara (MNRT), luego de la ruptura con Ezcurra. El periodista Bernardo Neustadt puede incluirse también en esta categoría.

Por otra parte, el guion traza hábilmente la evolución ideológica de Baxter y Nell. Ambos protagonistas son vectores del desarrollo de hechos políticos de más amplio alcance en un 
contexto sociopolítico marcado por la proscripción del peronismo. El episodio cuarto, “4. Revolucionarios de verdad", que narra la ruptura de Tacuara en dos facciones, inicia con una escena donde observamos a Baxter y Nell siguiendo con gran interés frente al televisor el aludido discurso del líder cubano Fidel Castro contra el "imperialismo" del gobierno de John Kennedy (Figura 7). La secuencia da paso a la discusión de ambos personajes con sus camaradas Ezcurra y García Elorrio. En el intercambio, los argumentos esgrimidos por Baxter recuperan ideas y figuras revolucionarias y antiimperialistas, como el proyecto liderado por Castro. Se destaca un detalle expresivo del dibujo: en la secuencia que recrea la fuerte pelea entre los líderes de Tacuara, un rojo intenso inunda los ojos de un agitado Baxter, sobresaliendo del resto de su rostro. Igual recurso notamos en la cara ensangrentada de García Elorrio, quien provoca verbalmente a Baxter y luego recibe una golpiza de éste. Asimismo, los fondos rojos de las viñetas en las que transcurre la pelea aportan el clima de tensión y violencia que anticipa el cisma de la organización.

Finalmente, reconocemos en la figura del comisario Evaristo Meneses un personaje híbrido entre lo monumental histórico y lo monumental ficcional. Este policía existió en la vida real con ese mismo nombre y gozó de notable reconocimiento en los medios de su época, la Argentina de mediados del siglo XX. El mito que fue llevado a la historieta en la serie Evaristo, un clásico del género policial publicado en la primera revista Fierro en los ochenta. El quinto episodio de Tacuara, "Asalto al Policlínico Bancario”, representa al temible "Comisario Evaristo" como el encargado de investigar el citado atraco de "100 mil dólares" (ver figura 9). Al introducirlo en la ficción, se teje una doble referencia: tanto a la figura histórica real, que efectivamente investigó y resolvió el caso en el "récord" de "36 horas", como al personaje de aquel clásico de la ficción historietística argentina. Sobre el final del episodio, debajo de la última viñeta, una línea de texto completa el homenaje "a los maestros Sampayo y Solano López”, autores de Evaristo. 
Figura 9. Quinto episodio de Tacuara, de Rodolfo Santullo y Dante Ginevra.

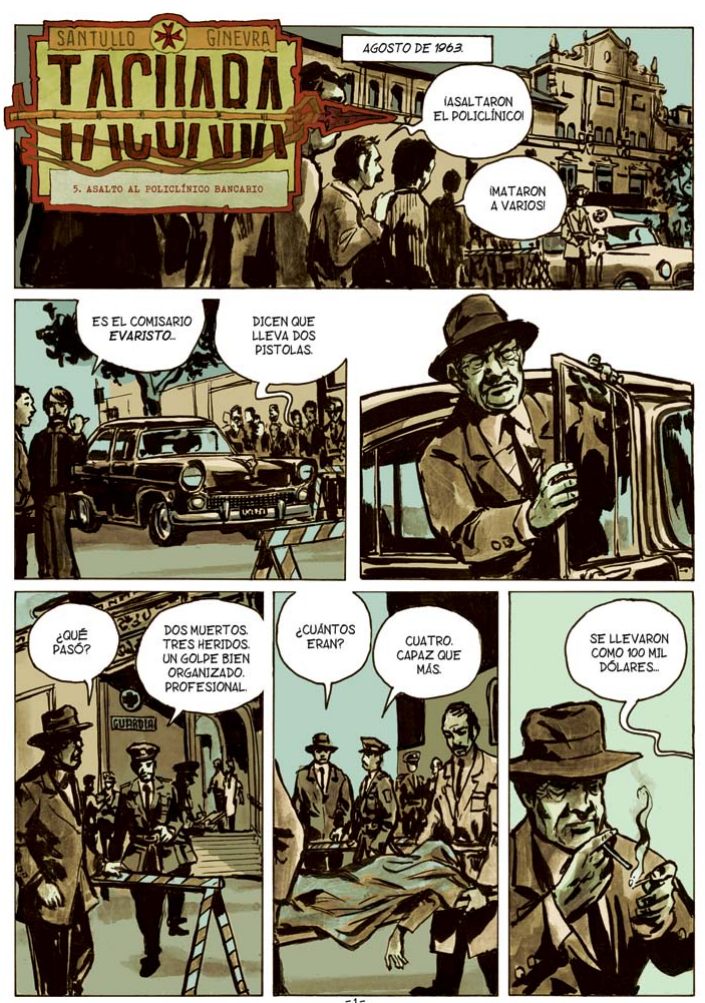

Fuente: SANTULLO, GINEVRA, Tacuara, en revista Fierro ${ }^{\circ}$ 69, julio de 2012, p. 67. Acervo del autor.

Los dos episodios finales de la serie, publicados entre noviembre y diciembre de 2012, fungen como cierre y síntesis de la historia, al recuperar el devenir de una agrupación política que completó una década de trayectoria, y los distintos y antitéticos caminos recorridos por sus líderes.

En el noveno episodio, el ostracismo político de Ezcurra se intercala, en la escritura y en la gráfica del relato, con los triunfos políticos de Baxter, siempre en la última viñeta de cada página. A este último se lo representa junto a líderes políticos como Fidel Castro, el vietnamita Ho Chi Minh, el líder de la guerrilla argentina Ejército Revolucionario del Pueblo, Roberto Santucho, y el siempre pendular Perón. Esos encuentros representan los mojones de una trayectoria política que evolucionó desde el nacionalismo de derechas reaccionario hacia una izquierda revolucionaria. Este episodio, como en buena parte de la construcción narrativa de Tacuara, se asienta en el diálogo de dos personajes, Alberto Ezcurra y su fiel ladero García Elorrio, que va dando paso a un racconto de acciones, referenciadas en sus 
diálogos. Dentro de la conversación se reproduce la públicamente conocida opinión que el inalterable Ezcurra tenía sobre la democracia: "Es una señora gorda, mal vestida, y con un acento extranjero". La intención del relato no es sino confirmar al personaje estancado en una visión del mundo antidemocrática y antipopular.

Para finalizar estas notas, nos detendremos en la última entrega ("10. En algún lugar cerca de París"), cuya trama gira en torno al accidente aéreo de julio de 1973 que acabó con la vida de José Baxter. La narración se asienta en la actuación del protagonista: mientras espera la muerte sentado en una butaca de avión, hace un racconto de su movediza vida política y de las amistades que lo marcaron. Las imágenes del siniestro aéreo acompañan sus pensamientos, que trazan los diametralmente opuestos perfiles político-ideológicos forjados por los protagonistas de la serie. La ficción aporta un recurso documental interesante: el accidente es presentado por una joven novicia católica que lee un recorte periodístico a Ezcurra, devenido sacerdote y confesor del futuro dictador de Argentina, el genocida Jorge Videla. Baxter, en tanto, es construido como un dirigente nutrido de una intensa y rica vida militante, partícipe de procesos revolucionarios ocurridos en Argentina, Uruguay, Vietnam, Cuba y Chile, entre otros países. En sus últimos pensamientos, Baxter le cuestiona a Ezcurra su conservadurismo inflexible y el no haber luchado por "un país mejor”: “¿Qué te pasó, Alberto? Vos querías un cambio. Veías que ese cambio era necesario” (...) ¿En qué momento te quedaste sólo en palabras? ¿En qué momento el odio te ganó la revolución?”. La amistad quebrada de los protagonistas encuentra un punto de redención en el fin mismo de Tacuara: tras enterarse de la muerte de su excamarada, Ezcurra lo despide en una mezcla de afecto y dolor (Figura 10).

La composición narrativa de ambos episodios no se sostiene en la sola presentación visual de documentos y monumentos de época, sino que los objetos históricos ficcionalizados (la trayectoria de la agrupación Tacuara, la muerte de uno de sus referentes, el devenir clerical y reaccionario del otro) son presentados discursivamente en su dimensión actual (Berone, 2020, p.21). La historieta dice cosas sobre determinados hechos del pasado, modelizando dos actuaciones históricas, las de los líderes y fundadores de Tacuara, Ezcurra y Baxter, con la intención de elaborar una particular lectura de un período crucial de la historia política argentina y de una parte de la historia del peronismo. 
Figura 10. Décimo y último episodio de Tacuara, de Rodolfo Santullo y Dante Ginevra.

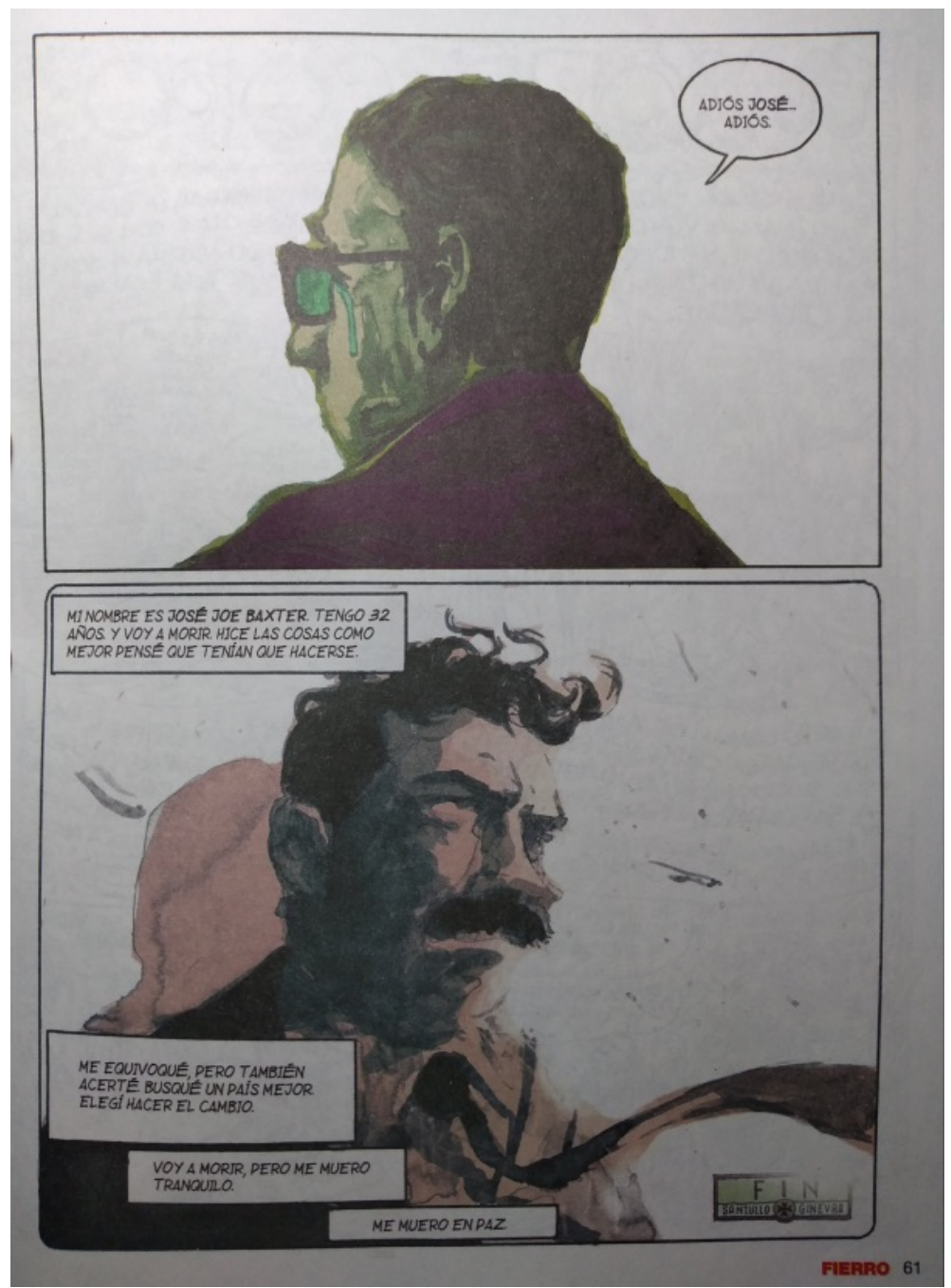

Fuente: SANTULLO, GINEVRA, Tacuara, en revista Fierro $n^{\circ}$ 74, diciembre de 2012, p. 61. Acervo del autor.

\section{Discusión}

En este trabajo, hemos analizado dos historietas de dos autores clave del cómic contemporáneo en la región del Río de la Plata, Rodolfo Santullo y Dante Ginevra. En ambas ficciones, publicadas en un momento particular de la revista Fierro en su "segunda época" (entre 2010 y 2012), los autores despliegan una serie de operaciones discursivas mediante las cuales la nueva historieta histórica rioplatense (NHHR) se constituye en un género de la narrativa gráfica con un valor específico. Valor fundado en la producción de memoria que, en el caso del cómic, funciona a través de la representación de un hecho u objeto histórico, 
pero afectado siempre de algún modo por la subjetividad que lo señala (Berone, 2020, p.10). Las distintas producciones de NHHR realizadas en la última década y media emplean una serie de artefactos como recipientes que recogen nuestro pasado y con los que se va edificando la memoria colectiva (Mendoza-García, 2014, p.5). En el caso de las obras analizadas, una más cercana al drama político y la otra al policial, los artefactos de memoria aparecen como "materiales" documentales y monumentales que producen sentido en relatos de carácter testimonial. El testimonio es una operación narrativa que teje cruces entre actuaciones históricas y las actuaciones menores, entre las cuales adquieren relevancia los nombres propios gráficos. En palabras de Berone (2020), en el trabajo social de elaboración de una memoria histórica, el testimonio permite instalar un resto, una falla entre la subjetividad y la Historia.

Al revisar las distintas estrategias de representación ficcional de objetos históricos que se dan cita en Malandras y Tacuara, nos es inevitable plantearnos que la historieta es tanto un medio de comunicación social como un lenguaje estético-expresivo desde el cual es posible la construcción de memoria y la revisión y recuperación del pasado dentro de un particular presente histórico, generando unos efectos específicos. Dada la naturaleza intrínseca del medio, esos efectos no pueden lograrse sino a partir de la generación de un excedente de lo real en la narración, espacio donde son puestas en secuencia gráfica las distintas actuaciones -históricas o no- que motorizan los relatos historietísticos.

\section{Financiamiento}

Esta investigación fue financiada por el Consejo Nacional de Investigaciones Científicas y Técnicas de Argentina, organismo donde me desempeño como Investigador Asistente.

\section{Conflicto de interés}

El autor declara que no existe conflicto de interés. Los financiadores no han tenido ningún rol en la producción del artículo. 


\section{Referencias bibliográficas}

BERONE, L. (2012). Historieta, discurso político y narración. La revista Fierro, entre dos épocas. En L. Berone \& F. Reggiani (Eds.), Creencias bien fundadas: Historieta y política en Argentina, de la transición democrática al kirchnerismo (pp. 40-6o). Universidad Nacional de Córdoba.

(2014). El sistema de los géneros en la historieta argentina contemporánea. El caso de la historieta histórica [Texto Inédito]. Universidad Nacional de Córdoba, Argentina.

(2018). La intención es joder un poco Algunas claves de lectura sobre la obra de Carlos Trillo. En S. Gago \& I. Lomsacov, Viñetas bajo la lupa. Algunas claves de lectura sobre historieta argentina. Universidad Nacional de Córdoba.

(2020). Historieta rioplatense y memoria histórica. Sobre algunas dificultades contemporáneas. 9a Arte, 9(1), pp. 14-34. https://doi.org/10.11606/issn.23169877.v9i1p14-34

BOURDIEU, P. (1995). Las reglas del arte. Génesis y estructura del campo literario. Anagrama.

ECO, U. (1984). Apocalípticos e integrados. Editorial Lumen.

FERNÁNDEZ, L. (2017). La historieta como relato de un trauma social en América Latina: los casos Historietas por la Identidad (Argentina) y Acto de Guerra (Uruguay). Miguel Hernández Communication Journal, (7), pp. 191-215. https://revistas.innovacionumh.es/index.php/mhcj/article/view/134/267

GOMBRICH, E. (1995). La Historia del Arte. Consejo Nacional para la Cultura y las Artes (Conaculta) y Editorial Diana.

HAMON, P. (1977). Para un estatuto semiológico del personaje. En R. Barthes et al., Poétique du récit (pp. 115-180). Seuil. 
LLADÓ-POL, F. (2001). Los cómics de la transición (El boom del cómic adulto 19751984). Glénat.

MARTínEZ-GUIDOLIN, V. (2015). Políticas de Memoria del pasado reciente en las ciudades de Montevideo y Buenos Aires. [Tesis de Maestría, Universidad de la República de Uruguay] https://www.colibri.udelar.edu.uy/jspui/bitstream/123456789/17033/1/TMFC S Mart\%C3\%ADnezGuidolinVirginia.pdf

MCCLOUD, S. (2016). Entender el comic. El arte invisible (5ta edición). Astiberri Ediciones.

MENDOZA-GARCÍA, J. (2014). La configuración de la memoria colectiva: los artefactos. Por caso, la escritura y las imágenes. Entreciencias. Diálogos en la

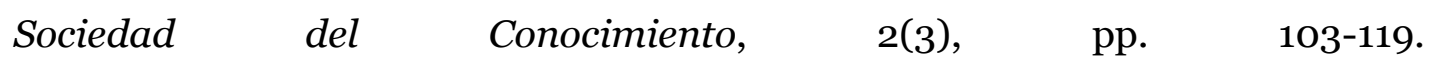
http://dx.doi.org/10.21933/J.EDSC.2014.03.041

REGGIANI, F. (julio 8, 2008). Historietas en transición. Representaciones del terrorismo de Estado durante la apertura democrática [Mensaje de foro en línea]. Estudios y Crítica de la Historieta Argentina. https://historietasargentinas.wordpress.com/2008/07/08/11-historietas-entransicion-representaciones-del-terrorismo-de-estado-durante-la-aperturademocratica-federico-reggiani/

(2012). Nombres propios, política y representación: Sarna y El Síndrome Guastavino. En L. Berone \& F. Reggiani (Eds.), Creencias bien fundadas. Historieta y política en Argentina, de la transición democrática al kirchnerismo (vol. 4, pp. 86-96). Universidad Nacional de Córdoba.

SANTUllO, R. \& GINEVRA, D. (2012). Tacuara. Revista Fierro. La historieta argentina. Ed. la Página. (2014). Malandras. Historieteca Editorial.

SASTURAIN, J. (2011). Contraindicaciones: Un número pesado. Revista Fierro. La 
historieta argentina, (55), pp. 4.

SAVOINI, S. \& SIRAGUSA, C. (mayo 7-9, 2014). Retratos de Guerra: memorias acerca de Malvinas en la TV argentina [Sesión de Congreso]. Congreso PreAlas Patagonia, VI Foro Sur-Sur. El Calafate, Argentina.

(2017). Los tiempos de la guerra / la guerra en el tiempo: una memoria televisiva de Malvinas. Representaciones. Revista de Estudios sobre Representaciones en $\begin{array}{lllll}\text { Arte, } & \text { Ciencia } & y & \text { Filosofía, } & \text { 13(2), }\end{array}$ https://revistas.unc.edu.ar/index.php/repr/article/view/19564

VALENZUELA, A. (mayo 18, 2011) Nace una asociación de historietistas. Cuadritos, periodismo de historieta. https://avcomics.wordpress.com/2011/05/18/7826/

VON-SPRECHER, R. (2012). Historieta, Estado, política y grados de autonomía. En L. Berone \& F. Reggiani (Eds.), Creencias bien fundadas. Historieta y política en Argentina, de la transición democrática al kirchnerismo (vol. 4, pp. 13-40). Universidad Nacional de Córdoba. 